\title{
Free Osteocutaneous Fibular Graft for Infected Bone Defect of the Ulna: Case Report
}

\author{
*Ricardo Monreal \\ Centro Medico MEDEX, San Isidro Lima, USA
}

Submission: March 25, 2017; Published: April 10, 2017

*Corresponding author: Ricardo Monreal, Centro Medico MEDEX, San Isidro Lima, Clinicas Maison de Sante, Ave Chorrillos 171, Chorrillos, Lima, Peru, USA, Email: rmonreal59@yahoo.es

\section{Abstract}

Vascularized bone graft is a well-accepted technique when dealing with long defects. In this paper the author presents a case with a chronically infected gap nonunion of the proximal ulna treated with a free vascularized fibular graft. Vascularized fibular graft is a reliable technique for reconstruction of bone defects of the forearm even in the presence of infection.

Keywords: Bone Defect; Vascularized Fibular Graft; Osteomyelitis and Infected non-union

\section{Introduction}

Fracture non-union or delayed union frequently occur after high-energy trauma, in open fractures with infections, inadequate osteosynthesis with unsatisfactory stabilization or with persistence of infection, but failure mostly occur in bony defects greater than $6 \mathrm{~cm}[1,2]$. In the past, segmental bone loss in the forearm has been a difficult orthopaedic problem but vascularized bone graft became rapidly popular to solve defects in the most unfavorable scenarios (infected, scarred or irradiated beds) [3-7]. We report a case of infected nonunion of the proximal ulna managed with vascularized fibular graft as an osteoseptocutaneous flap. At nine months follow up, the patient is symptom free and is able to carry out his daily activities.

\section{Case Report}

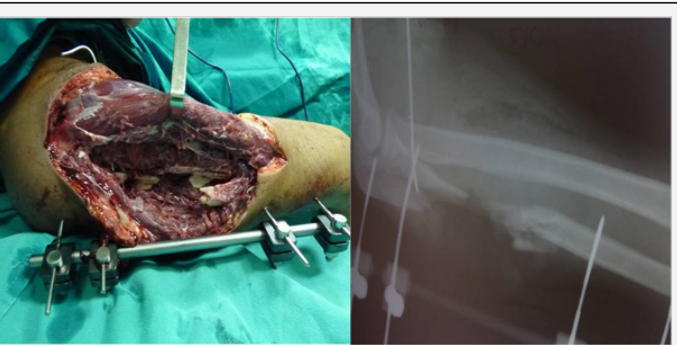

Figure 1: Clinical case example of a patient with an infected fracture nonunion and bone defect of the proximal ulna.

A 48-year-old man presented to our Out Patient Department with an infected gap nonunion of the right proximal ulna, presented 6 months after an open Monteggia fracture (Figure 1).

\section{Surgical Technique}

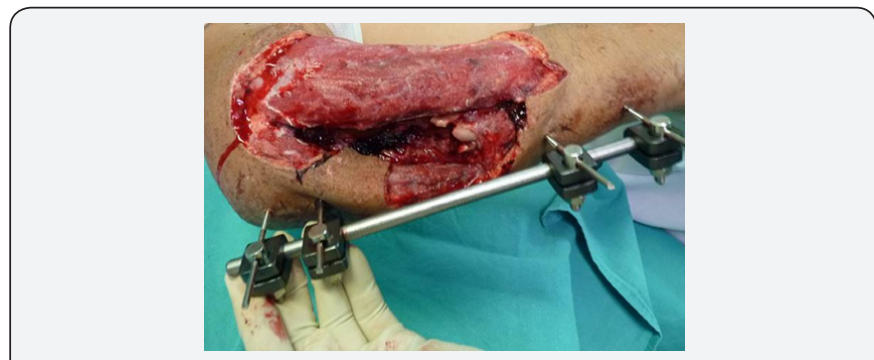

Figure 2: Debridement of the wound and resection of bone infected.

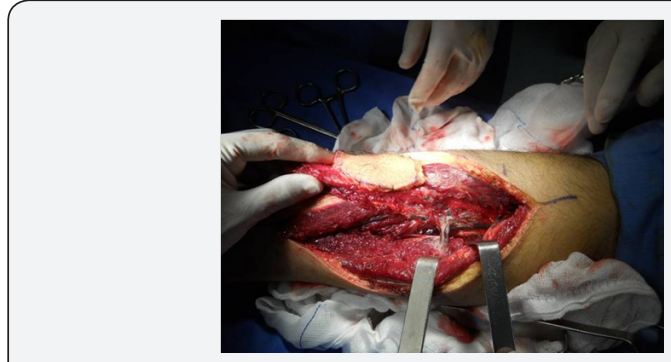

Figure 3: Free osteocutaneous fibula graft with microvascular transfer. Skin paddle for soft-tissue augmentation and monitoring.

Under general anaesthesia and the infected wound track was cleared through debridement until the soft tissue bed appeared red and bleeding (Figure 2). The proximal and distal stump ends were cut to create a fresh vascularized bony ends. Then the bone 
gap was measured intra operatively to $10 \mathrm{~cm}$ and both ends were drilled with $2.7 \mathrm{~mm}$ drill bit to open medullary cavity. The fibular graft was harvested as an osteoseptocutaneous flap based on septocutaneous perforators along the posterior crural septum following the technique described by Wei et al. [8] and later by Wei and El-Gammal [5] (Figure 3).

The patient is placed in the supine position with a bump under the contra lateral hip to lessen the need for excessive internal rotation of the lower leg. A well-padded tourniquet is placed on the thigh and the leg from the knee down is prepped and draped. The proximal and distal fibula was marked and the axis of the bone is drawn. The axis of the skin paddle is drawn at the posterior border of the fibula. The anterior flap was elevated just above the muscle and deep to the muscular fascia. The septum was approached by elevating the fascia from anterior to posterior and septal perforators were seen. This requires dissection through the anterior aspect of the soleus muscle. The skin paddle was raised from the posterior approach noting and preserving muscular perforators. A small cuff of muscle - a millimeter or less - was left attached to the fibular bone. ArmyNavy retractors helped provide counter traction as the muscle was peeled away leaving behind a cuff of muscle overlying periosteum on bone.

When the bone gap of the ulna is determined, the fibula was harvested 2-3 cm longer than the length of the bone defect, the superior and inferior locations of the planned osteotomy are marked, a right angle retractor was used to snugly encircle the bone. Care is taken to hug the bone so that the vessels are not captured. The distal 6-7 centimeters of bone are preserved to spare the ankle mortise and the proximal course of the peroneal nerve is marked at the neck of the fibula to spare the nerve. Homan retractors are used to protect the soft tissue when the osteotomy is made with an oscillating saw. Bone clamps were placed at the superior and inferior ends of the flap to help provide anterior and posterior traction on the interosseous membrane (Figure 4).

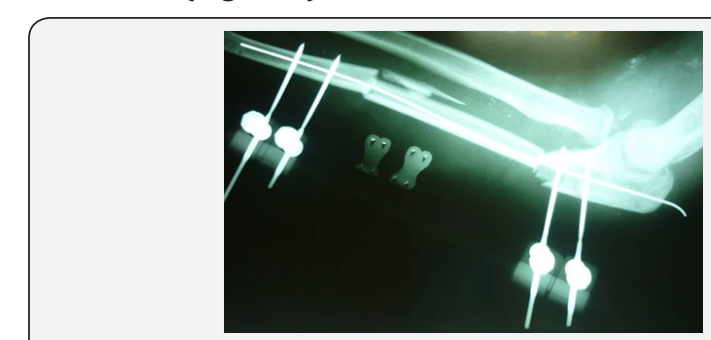

Figure 4: An external fixator and intramedullary Kirschner wire were used to stabilize the fibular graft.

The interosseous membrane was divided and the peroneal artery and the accompanying venae were seen. The distal aspect of the artery and veins are ligated and divided, and the flap can then be raised superiorly on the vascular pedicle. The tourniquet can then be deflated to obtain hemostasis and ensure good blood flow to the foot. The ankle was splinted in neutral and the patient is allowed to ambulate in a cast shoe at about a week after surgery. Postoperative monitoring of the skin pedal of the osteoseptocutaneous fibular flap was performed through a small window in the wound. Administration of parenteral antibiotics was continued for 2 weeks). The stitches were removed after 2 weeks. Six weeks later, the external fixation and intramedullary Kirschner wire were removed and the ulna was stabilized with two plates. The final evaluation consisted of clinical assessment according to the Tang [6,7] and radiographic evidence of bone union. Nine months after surgery the clinical evaluation on the basis of the Tang system was excellent (Figure 5a), and radiographic examination demonstrated that bony union had been achieved (Figure 5b).

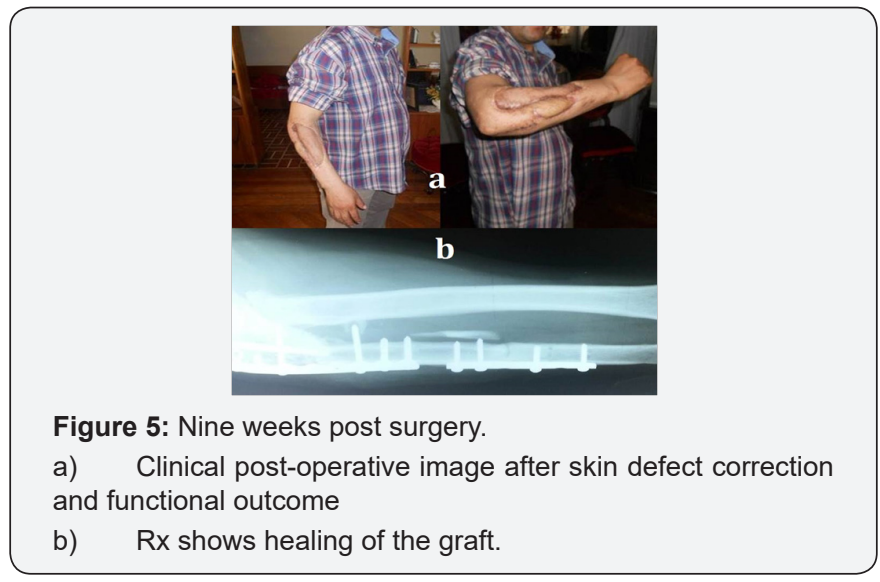

\section{Discussion}

Large skeletal and soft tissue defects about the forearm present one of the most challenging problems for both orthopedic and plastic surgeons. Several surgical options for the treatment of upper limb bone non-union (intramedullary nailing, distraction with external fixator, and plate compression) with or without conventional bone grafting) have been described but failure mostly occurs in bony defects greater than $6 \mathrm{~cm}[1,2]$. The use of these techniques has limitations. Nonvascularized bone graft needs a prolonged time of immobilization and its use is contraindicated in infected, poorly vascularized, and irradiated areas $[8,9]$. Bone transport using the external fixation has limited use in bone defects of the forearm because of the high rate of complications (pin-track infection, delayed union, and refracture) [10-12].

Reconstruction of free fibula flap in long bones is a useful and versatile procedure for defects greater than $6-8 \mathrm{~cm}[1,2]$. The overall success rate of the reconstruction with free vascularized fibular grafts, as estimated from literature, varies from $76 \%$ to $100 \%$, with a healing time in the 3.7-8.9 months interval [7]. The fibula is a long and straight tubular bone with a vascular supply well established $[13,14]$ which is not difficult to harvest, as long as the donor site morbidity is minimal, up to a graft length of $20 \mathrm{~cm}$, it can be transferred as a composite osteocutaneous or osteomuscular flap, and the peroneal vessels are of sufficient 
diameter to facilitate the micro vascular anastomosis. Free fibula transfer was originally described in 1975 by Taylor et al for reconstruction of an open fracture of the leg [15]. Later, Gilbert is credited with the more commonly used lateral approach (x).2 All of these were nonskin-bearing flaps. Chen and Yan were the first to delineate the successful use of osteomyocutaneous fibula free tissue transfer [16].

In 1982, Hurst et al. [17] published the first report of the application of this method to a large, previously infected defect in the proximal ulna obtaining bony union and control of infection, and its application in posttraumatic reconstruction of the forearm has also gained increased popularity over the last few decades [17-20]. The reason for this are (a) increased vascularity at the fracture site is essential in promoting a faster bone healing and fighting infection and (b) vascularized bone provides higher biomechanical strength than nonvascularized bone [21]. In this case report, external fixation supplemented with a thin intramedullary k-wire (as a guide) during the first postoperative 6 weeks, provided stable immobilization for the vascularized graft avoiding the risks associated with plates at the infected site. The donor-site morbidity was absent.

\section{Conclusion}

Vascularized fibular graft has proved as a useful option in our patient. Successful outcome makes it a reliable technique for reconstruction of bone defects even in the presence of infection.

\section{Author's Disclosure Statement}

The author reports no actual or potential conflict of interest in relation to this article.

\section{References}

1. Heitmann C, Erdmann D, Levin LS (2002) Treatment of segmental defects of the humerus with an osteoseptocutaneous fibular transplant. J Bone Joint Surg Am 84: 2216-2223.

2. Tu YK, Yen CH, Yeh WL, Wang IC, Wang KC, et al. (2001) Reconstruction of posttraumatic long bone defect with free vascularized bone graft: good outcome in 48 patients with 6 years follow-up. Acta Orhop Scand 72(4): 359-364.

3. Pho RW (1979) Free vascularized fibular transplant for replacement of the lower radius. J Bone Joint Surg Br 61-B(3): 362-365.

4. Weiland AJ, Kleinert JE, Kutz JE, Daniel RK (1979) Free vascularized bone grafts in surgery of the upper extremity. J Hand Surg 4(2): 129143.

5. Wei FC, El Gammal TA (1999) Free vascularized bone grafts and osteocutaneous flaps. In: Georgiade GS, Riefkonl R, Levin LS, (Eds)
Plastic, maxillofacial and reconstructive surgery. $3^{\text {rd }}$ edn, William and Wilkins, Baltimore, USA, pp. 940-945.

6. Tang CH (1992) Reconstruction of the bones and joints of the upper extremity by vascularized free fibular graft: report of 46 cases. J Reconstr Microsurg 8(4): 285-292.

7. Adani R, Delcroix L, Innocenti M, Marcoccio I, Tarallo L, et al. (2004) Reconstruction of large posttraumatic skeletal defects of the forearm by vascularized free fibular graft. Microsurgery 24(6): 423-429.

8. Stevanovic M, Gutow AP, Sharpe F (1999) The management of bone defects of the forearm after trauma. Hand Clin 15(2): 299-318.

9. Mankin HJ, Gebhardt MC, Tomford WW (1987) The use of frozen cadaveric allografts in the management of patients with bone tumors of the extremities. Orthop Clin North Am 18(2): 275-289.

10.Villa A, Paley D, Catagni MA, Bell D, Cattaneo R (1990) Lengthening of the forearm by the Ilizarov technique. Clin Orthop Relat Res 250: 125-137.

11. Emara KM (2002) Ilizarov technique in management of non-united fracture of both bones of the forearm. J Orthop Traumatol 3(3):177180.

12. El Mowafi H, Elalfi B, Wasfi K (2005) Functional outcome following treatment of segmental skeletal defects of the forearm bones by Ilizarov application. Acta Orthop Belg 71(2): 157-162.

13. Taylor GI, Miller GDH, Ham FJ (1975) The free vascularized bone graft: a clinical extension of micro vascular techniques. Plast Reconstr Surg 55(5): 533-544.

14. Malizos KN, Zalavras CG, Soucacos PN, Beris AE, Urbaniak JR, et al. (2004) Free vascularized fibular grafts for reconstruction of skeletal defects. J Am Acad Orthop Surg 12(5): 360-369

15. Taylor GI, Miller GDH, Ham FJ (1975) The free vascularized bone graft: a clinical extension of microvascular techniques. Plast Reconstr Surg 55(5): 533-544.

16. Chen ZW, Yan W (1983) The study and clinical application of the osteocutaneous flap of fibula. Microsurgery 4(1): 11-16

17. Hurst LC, Mirza A, Spellman W (1982) Vascularized fibular graft for infected loss of the ulna: Case report. J Hand Surg 7(5): 498-501.

18. Chuang DC, Chen HC, Wei FC, Noordhoff MS (1992) Compound functioning free muscle flap transplantation (lateral half of soleus, fibula, and skin flap). Plast Reconstr Surg 89(2): 335-339.

19. Jones NF, Swartz WM, Mears DC, Jupiter JB, Grossman A (1988) The "double barrel" free vascularized bone graft. Plast Reconstr Surg 81(3): 378-385.

20. Koshima I, Higaki H, Soeda S (1991) Combined vascularized fibula and peroneal composite flap transfer for severe heat-press injury of the forearm. Plast Reconstr Surg 88(2): 338-341.

21. Mattar JJ, Azze RJ, Castro Ferreira M, Starck R, Canedo AC (1994) Vascularized fibular graft for management of severe osteomyelitis of the upper extremity. Microsurgery 15(1): 22-27. 
(i) This work is licensed under Creative BY
Your next submission with Juniper Publishers will reach you the below assets

- Quality Editorial service

- Swift Peer Review

- Reprints availability

- E-prints Service

- Manuscript Podcast for convenient understanding

- Global attainment for your research

- Manuscript accessibility in different formats (Pdf, E-pub, Full Text, Audio)

- Unceasing customer service

Track the below URL for one-step submission https://juniperpublishers.com/online-submission.php 